\title{
4 - Flood plains: critically threatened ecosystems
}

Klement Tockner, Stuart E. Bunn, Christopher Gordon, Robert J. Naiman, Gerry P. Quinn and Jack A. Stanford

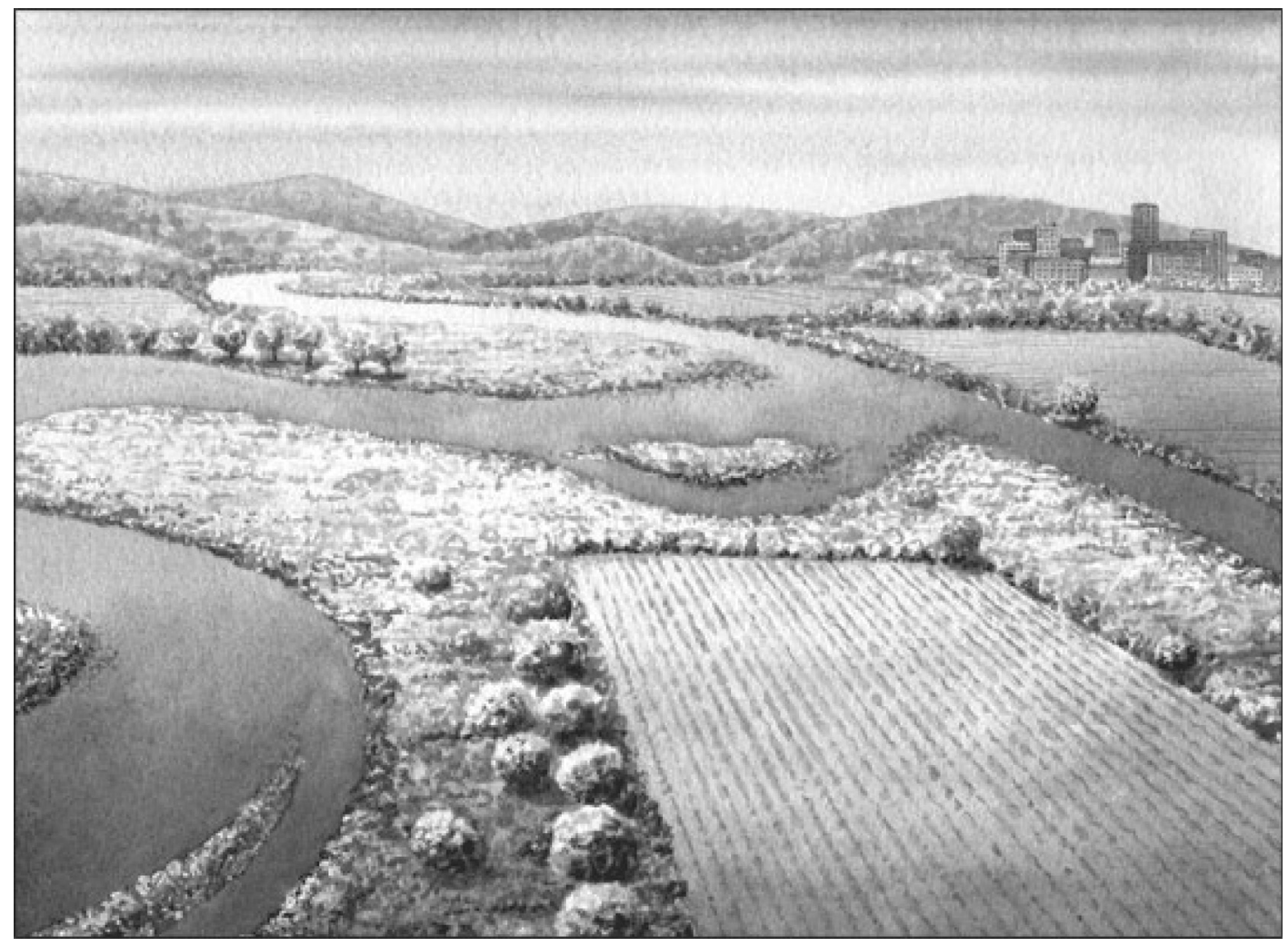

\section{INTRODUCTION}

Riparian zones, river-marginal wetland environments and flood plains are key landscape elements with a high diversity of natural functions and services. They are dynamic systems that are shaped by repeated erosion and deposition of sediment, inundation during rising water levels, and complex groundwater-surface water exchange processes (Chapter 3). This dynamic nature makes flood plains among the most biologically productive and diverse ecosystems on earth (Junk et al. 1989; Gregory et al. 1991; Naiman \& Décamps 1997; Tockner \& Stanford 2002; Naiman et al. 2005). Flood plains are also of great cultural and economic importance; most early civilizations arose in fertile flood plains and throughout history people have learned to cultivate and use their rich resources. Flood plains have also served as focal points for urban development and exploitation of their natural functions.

Aquatic Ecosystems, ed. N. Polunin. Published by Cambridge University Press. @ Foundation for Environmental Conservation 2008. 
Awareness has been growing during the past decade of the global significance of freshwater biodiversity, of the array of factors that have (or will have) threatened it and the extent to which real damage has already been done (Abramovitz 1996; McAllister et al. 2000). Flood plains in particular have been highly degraded throughout the world by river and flow management and by land-use pressures. Nowadays, they are among the most endangered ecosystems worldwide (Olson \& Dinerstein 1998). Accordingly, flood plains deserve increased attention for their inherent biodiversity, for the goods and services provided to human societies and for their aesthetic and cultural appeal.

This chapter builds upon a recent comprehensive environmental review of riverine flood plains (Tockner \& Stanford 2002). It starts with a short summary of the distribution and extent of the world's flood plains, followed by an overview of their primary economic, ecological and cultural values. The multifaceted threats that make flood plains one of the most endangered landscape elements worldwide are then discussed. Finally, future trends in floodplain exploitation in developing and developed countries are contrasted, and the ecological consequences of rapid alteration of floodplain ecosystems forecasted. Since flood plains, wetlands and river systems are not always clearly distinguished, general examples of rivers or floodplain wetlands are included in the present review when appropriate. The flood-inundated wetlands and lakes of the humid tropics are treated in more detail later (Chapter 10).

\section{FLOOD PLAIN DISTRIBUTION}

Flood plains are defined as 'areas of low lying land that are subject to inundation by lateral overflow water from rivers or lakes with which they are associated' (Junk \& Welcomme 1990) (Fig. 4.1). This definition includes fringing flood plains of lakes and rivers, internal deltas and the deltaic flood plains of estuaries. Brinson (1990) and Brinson and Malvaréz (2002; Chapter 9) proposed a hydrogeomorphic classification of wetlands based on the (1) geomorphic setting, (2) water source and (3) hydrodynamics. Considering these components, riverine flood plains are located on lowgradient alluvial 'shelves' and water originates primarily from lateral overspill of rivers, although other water sources (groundwater, precipitation) may significantly contribute to inundation (see for example Mertes 2000).

Although accurate global assessments of wetlands are elusive due to the complexity and highly dynamic nature of wetlands and floodplain ecosystems (Finlayson \& Davidson
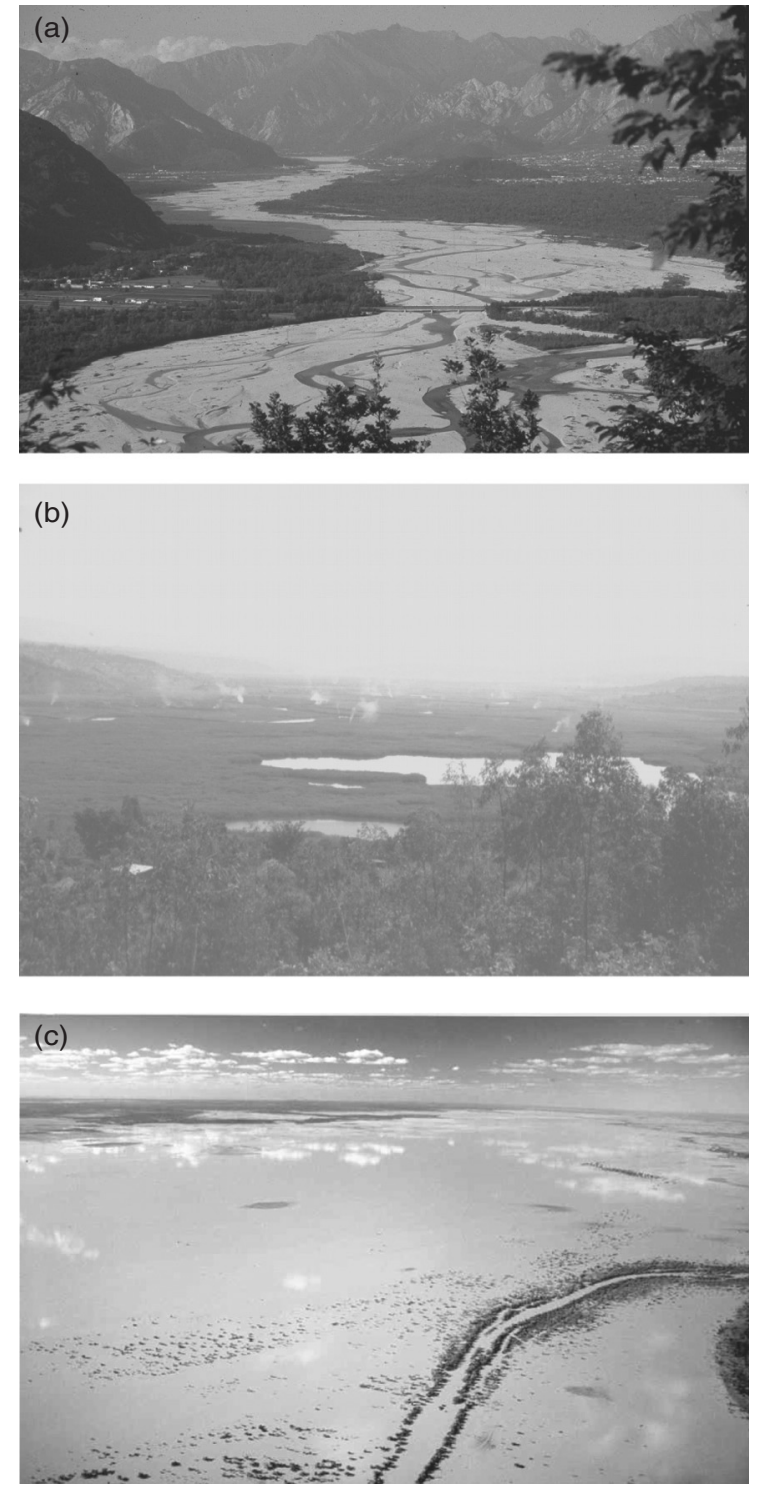

Fig. 4.1. (a) Tagliamento River, Italy, a semi-natural braided floodplain corridor in Central Europe (photograph: K. Tockner). (b) Flood plains along the Nyaborongo/Akagera River, Rwanda, Africa, colonized by dense stands of Papyrus cyperus

(photograph: K. Tockner). (c) Cooper Creek in the Lake Eyre Basin, Australia, at the height of a flood in March 2000, which covered approximately $14000 \mathrm{~km}^{2}$ (photograph: R. Ashdown).

1999), wetlands cover nearly 10\% of the Earth's land surface and of this $15 \%$ are flood plains (Ramsar [Ramsar Secretariat] \& IUCN [World Conservation Union] 1999). Total global floodplain area estimates range from $0.8 \times 10^{6} \mathrm{~km}^{2}$ 
Table 4.1. Global extent of flood plains that are functionally largely intact, and major human threats

\begin{tabular}{|c|c|c|c|}
\hline Region & River systems & $\begin{array}{l}\text { Floodplain } \\
\text { area }\left(\mathrm{km}^{2}\right)^{a}\end{array}$ & Major impacts \\
\hline Africa & Nile (Sudd), Congo basin, Niger & 310000 & Hydrological change \\
\hline Europe & Danube and Volga deltas & 40000 & Embankment, drainage \\
\hline North America (USA) & $50 \%$ in Alaska, Mississippi & 240000 & $\begin{array}{l}\text { Embankment, hydrological } \\
\text { change, drainage }\end{array}$ \\
\hline South America & Primarily Amazonian basin & 1100000 & Urbanization \\
\hline $\begin{array}{l}\text { South-East Asia } \\
\text { (including China) }\end{array}$ & Mekong, Irrawaddy & 400000 & $\begin{array}{l}\text { Urbanization, hydrological } \\
\text { change }\end{array}$ \\
\hline Australasia & $\begin{array}{l}\text { Fly River, Paroo River and } \\
\text { Cooper Creek }\end{array}$ & 150000 & Hydrological change \\
\hline Russia/Central Asia & Lena, Mongolia & unknown & Climate change \\
\hline Total & & 2240000 & \\
\hline
\end{tabular}

${ }^{a}$ Conservative estimation of area based on Tockner and Stanford (2002) and Table 4.2. A clear separation of individual wetland types is often difficult (e.g. flood plains, marshes and swamps).

(Aselmann \& Crutzen 1989), to $1.65 \times 10^{6} \mathrm{~km}^{2}$ (flood plains and swamps: Costanza et al. 1997) and $2.2 \times 10^{6} \mathrm{~km}^{2}$ (flood plains along rivers and lakes: Ramsar \& IUCN 1999) (Tables 4.1 and 4.2).

Based on data from 145 major river corridors around the world, the extent of human impacts on riparian zones is apparent (Fig. 4.2a). For example, 11\% of the riparian area of African rivers (mean population density 24 people $\mathrm{km}^{-2}$ ) is intensively cultivated, compared to $46 \%$ for North American rivers (mean population density, excluding northern Canada and Alaska, 24 people $\mathrm{km}^{-2}$ ) and 79\% for European rivers (mean population density 75 people $\mathrm{km}^{-2}$ ). The most impacted riparian corridors with respect to land use are found in Europe and in the densely populated areas of Asia (catchments with population densities $>200$ people $\mathrm{km}^{-2}$ ) (Fig. 4.2a). There, $60-99 \%$ of the entire riparian corridor has been transformed into cropland and/or is urbanized, the latter particularly so in Europe, where the Seine River (France) shows the highest impact of all rivers investigated. Along Asian and African river corridors, there is a highly significant linear relationship between human population density and the rate of land transformation. Along European and American corridors the relationship is logarithmic (Tockner \& Stanford 2002). The analysis considers only those areas with intensive agricultural development, excluding mosaics of cropland and natural vegetation. Therefore, a more traditional and perhaps a more sustainable use of riparian and floodplain areas can explain the low levels of land use for African and many Asian river corridors. This does not imply, however, that flood plains with little intensive agricultural development or low population densities have not been markedly impacted in these regions (Chapter 3). For example, construction of impoundments, water harvesting and floodplain development (for example on-farm storages and levees) in Australia have reduced flooding of many wetlands, and changes in aquatic plant communities have occurred together with declines in abundances of waterbirds, fish and invertebrates. As a direct result of river regulation, and deliberate filling and draining, most of the wetlands in south-eastern Australia have been destroyed. About $90 \%$ of the floodplain wetlands in the Murray-Darling Basin, $75 \%$ of the coastal wetlands of New South Wales and 75\% of Swan Coastal Plain wetlands in south-western Australia have been lost (Bunn et al. 1997).

Today, the largest remaining flood plains are in South America where about $20 \%$ of tropical lowlands are flooded annually (Junk 2002). In Africa, many large flood plains are still relatively untouched (for example Sudd, Congo Basin). However, they are disappearing or are being transformed at an accelerating rate as a result of watermanagement activities, in particular by large-scale irrigation schemes and the ongoing construction of dams (Gordon 2003). In the USA, flood plains originally covered $7 \%$ or 
Table 4.2. Distribution and extent of selected fringing riverine flood plains (including a fem rain-fed flood plains)

\begin{tabular}{|c|c|c|}
\hline Drainage system/geographical area & Area $\left(\mathrm{km}^{2}\right)^{a}$ & Major flood plains/comment/reference \\
\hline \multicolumn{3}{|l|}{ Africa $^{b}$} \\
\hline Zaire/Congo system & 70000 & Middle Congo depression, Kamulondo, Malagarasi \\
\hline Niger/Benue system & 38900 & Niger central delta, Benue River \\
\hline Nile system & 93000 & Sudd, Kagera basin \\
\hline Zambezi system & 19000 & Kafue flats, Barotse plain, Liuwa plain \\
\hline Western systems & 19000 & Flood plains along the Senegal (excluding delta), Volta and Ouémé \\
\hline South-east systems & 100 & Pongolo flood plain \\
\hline Eastern systems & 8600 & Kilombero, Rufiji, Tana River \\
\hline Chad system $^{c}$ & 63000 & Chari and Lagone River system \\
\hline Gash river & 3000 & $\begin{array}{l}\text { Inner delta in Sudan (primarily woodland and savannah; Kirkby \& } \\
\text { O'Keefe 1998) }\end{array}$ \\
\hline Tana delta & 670 & Endangered by upstream dams (Hughes 1990) \\
\hline \multicolumn{3}{|l|}{ Europe } \\
\hline Switzerland & 200 & $\begin{array}{l}\text { A total of } 234 \text { flood plains of national importance (Forum } \\
\text { Biodiversität Schweiz 2004) }\end{array}$ \\
\hline The Netherlands & 498 & $\begin{array}{l}\text { Area regularly flooded by rivers (primarily meadows; Yon \& } \\
\text { Tendron 1981) }\end{array}$ \\
\hline Danube National Park, Austria & 93 & $\begin{array}{l}\text { The last remaining semi-natural flood plain along the Upper } \\
\text { Danube (Tockner et al. 2000) }\end{array}$ \\
\hline Tagliamento & 150 & $\begin{array}{l}\text { The last morphologically intact river corridor in the Alps (Tockner } \\
\text { et al. 2003) }\end{array}$ \\
\hline $\begin{array}{l}\text { Lonjsko polje (Save River), } \\
\text { Croatia }\end{array}$ & 507 & $\begin{array}{l}\text { One of largest and best-preserved flood plains in Europe (Spanjol } \\
\text { et al. 1999) }\end{array}$ \\
\hline Kopacki rit, Croatia & 177 & $\begin{array}{l}\text { Semi-natural flood plain at the intersection of the Danube and the } \\
\text { Drava (Spanjol et al. 1999) }\end{array}$ \\
\hline Upper Rhine & $70^{d}$ & $\begin{array}{l}\text { Originally, flood plains covered } 1000 \mathrm{~km}^{2} \text { (Carbiener \& Schnitzler } \\
\text { 1990) }\end{array}$ \\
\hline $\begin{array}{l}\text { French Rhône (fringing flood } \\
\text { plain) }\end{array}$ & 70 & $\begin{array}{l}\text { Mostly functionally extinct flood plains. Former extent } 830 \mathrm{~km}^{2} \\
\text { (Bravard 1987) }\end{array}$ \\
\hline Rhône delta, Carmargue & 750 & Former delta of $1644 \mathrm{~km}^{2}$ (Bravard 1987) \\
\hline Guadiana river, Spain & 450 & $\begin{array}{l}\text { Floodplain marshes in the Donana National and Nature Parks } \\
\text { (Benayas et al. 1999) }\end{array}$ \\
\hline $\begin{array}{l}\text { Danube main stem (including } \\
\text { delta) }\end{array}$ & 17400 & Mostly disconnected, therefore functionally extinct \\
\hline Danube delta & 5800 & $\begin{array}{l}\text { Danube Delta Biosphere Reserve, } c .50 \% \text { of this area belongs to the } \\
\text { 'Danube Delta' (RIZA 2000) }\end{array}$ \\
\hline Danube islands, Bulgaria & 107 & $\begin{array}{l}75 \text { islands in the main stem (Bulgarian Ministry of Agriculture and } \\
\text { Forests, unpublished report 2001) }\end{array}$ \\
\hline Dnieper river delta, Ukraine & $c .500$ & $\begin{array}{l}\text { Hydrologic impact by unpredictable flood releases from upstream } \\
\text { dams, pollution (Timchenko et al. 2000) }\end{array}$ \\
\hline Elbe river, Germany & 840 & Original extent $6170 \mathrm{~km}^{2}$ (Helms et al. 2002) \\
\hline Volga delta & 18000 & Largest European delta (Czaya 1981) \\
\hline $\begin{array}{l}\text { Tisza, Hungary, Ukraine and } \\
\text { Romania }\end{array}$ & 1800 & $\begin{array}{l}\text { Remaining area represents only } 4.7 \% \text { of former flood plains } \\
\text { (Haraszthy 2001) }\end{array}$ \\
\hline
\end{tabular}


Table 4.2. (cont.)

\begin{tabular}{|c|c|c|}
\hline Drainage system/geographical area & Area $\left(\mathrm{km}^{2}\right)^{a}$ & Major flood plains/comment/reference \\
\hline Poland & 820 & $\begin{array}{l}\text { Originally, floodplain forests covered } 27800 \mathrm{~km}^{2} \text { (Sienkiewicz et al. } \\
\text { 2001) }\end{array}$ \\
\hline European part of Russia & 9000 & Approximate estimation (Shatalov 2001) \\
\hline \multicolumn{3}{|l|}{ North America } \\
\hline Ogeechee & 150 & Subtropical river in south-east USA (Benke et al. 2000) \\
\hline Kissimmee (Lower basin) & 180 & $\begin{array}{l}\text { Disconnected at present, will be partly restored (see Warne et al. } \\
\text { 2000) }\end{array}$ \\
\hline Altamaha and Tone rivers & 400 & Mertes (2000) \\
\hline Upper Mackenzie river & 60000 & A complex of marshes, fens and flood plains (Fremlin 1974) \\
\hline Mackenzie delta & 13000 & Including 24000 lakes (Marsh et al. 1999) \\
\hline Lower Missouri river flood plain & 7700 & $\begin{array}{l}\text { At present mainly agricultural land (D. Galat, personal } \\
\text { communication 2003) }\end{array}$ \\
\hline Mississippi River flood plain & 20000 & $\begin{array}{l}\text { Remaining bottomland hardwood forests out of formerly } 85000 \mathrm{~m}^{2} \\
\text { (Llewellyn et al. 1996) }\end{array}$ \\
\hline Rock Mountain states, USA & $c .4000$ & Abernethy and Turner (1987) \\
\hline Washington and Oregon & 12500 & Abernethy and Turner (1987) \\
\hline Alaska & 120000 & c.50\% of present floodplain area in USA (Mitsch \& Gosselink 2000) \\
\hline Pánuco river, Mexico & 1400 & $\begin{array}{l}\text { Inundated area excluding permanent waters (Hudson \& Colditz } \\
\text { 2003) }\end{array}$ \\
\hline
\end{tabular}

\section{South America}

Amazon river

890000

Large and small river flood plains combined (Aselman \& Crutzen 1989; Sippel et al. 1998)

Orinoco delta

30000

Orinoco fringing flood plain

Pantanal

7000

Complex of flood plains, marshes and swamps (Groombridge 1992)

Parana

130000

Hamilton and Lewis (1990)

Magdalena

20000

The 'largest' single wetland complex on Earth (Hamilton et al. 1996)

Flooding pampa grassland,

20000

Fringing flood plains (Welcomme 1979)

Argentina

90000

Deltic flood plain (Welcomme 1979)

$80 \%$ of the area still covered by natural grasslands, fed by rain

(Perelman et al. 2001)

Asia

China

80000

Riverine and partly lacustrine wetlands in the Yangtze and Yellow-

Huaihe Basin (Lu 1995)

Lena and Yana deltas

$38700 \quad$ Largest northern delta complex

Mekong, Kampuchea 11000

Irrawaddy, Burma

Inundated forests along the Mekong and the shores of Le Grand Lac (Pantulu 1986)

Indonesia

31000

Welcomme (1979)

Bangladesh

119500

Primarily in Kalimantan and Irian Jaya (Lehmusluoto et al. 1999)

$98000 \quad$ Primarily cultivated, including $28000 \mathrm{~km}^{2}$ of rice fields (Welcomme 1979)

Ganges and Brahmaputra, India

Flood-prone area, heavily cultivated (FAO, unpublished report 2001a)

Yellow river, China

120000 Including parts of the Hai and Huai Rivers (DHI Water \& Environment, unpublished report 2001) 
Table 4.2. (cont.)

\begin{tabular}{|c|c|c|}
\hline Drainage system/geographical area & Area $\left(\mathrm{km}^{2}\right)^{a}$ & Major flood plains/comment/reference \\
\hline Tigris and Euphrates & 20000 & $\begin{array}{l}\text { Mesopotanic region; cultivated flood plain (Al Hamed 1966); about } \\
7600 \mathrm{~km}^{2} \text { has disappeared since } 1973 \text { (UNEP, unpublished report } \\
2001 a \text { ) }\end{array}$ \\
\hline \multicolumn{3}{|l|}{ Australasia } \\
\hline Fly river, Papua New Guinea & 45000 & Swales et al. (1999) \\
\hline Kakadu National Park, Australia & 260 & $13 \%$ of the park area (Gill et al. 2000) \\
\hline $\begin{array}{l}\text { Lower Balonne flood plain, } \\
\text { Australia }\end{array}$ & 2460 & Sims \& Thoms (2002) \\
\hline Chowilla anabranch, Australia & 200 & $\begin{array}{l}\text { Largest remaining natural floodplain forest along the lower Murray } \\
\text { river (Jolly 1996) }\end{array}$ \\
\hline $\begin{array}{l}\text { Cooper Creek and Paroo river, } \\
\text { Australia }\end{array}$ & 106000 & Endorheic flood plains in Central Australia (Kingsford et al. 1998) \\
\hline
\end{tabular}

${ }^{a}$ Area of flood plain is shown during the season of maximum inundation (extended from Tockner \& Stanford 2002). The reported areas differ substantially between reference sources, for example Upper Nile Swamps (Sudd): $>30000 \mathrm{~km}^{2}$ (Mitsch \& Gosselink 2000), $50000 \mathrm{~km}^{2}$ (Groombridge 1992), >90 $000 \mathrm{~km}^{2}$ (Howard-Williams \& Thompson 1985). Central Niger Delta: $30000 \mathrm{~km}^{2}$ (Howard-Williams \& Thompson 1985), $320000 \mathrm{~km}^{2}$ (Mitsch \& Gosselink 2000). Middle Congo depression: $70000 \mathrm{~km}^{2}$ (Howard-Williams \& Thompson 1985), $200000 \mathrm{~km}^{2}$ (Mitsch \& Gosselink 2000). Several major 'flood plains' listed are composed of different wetland types including swamps, wet grasslands or shallow lakes (for example Kagera valley, Central Congo basin, Sudd, Orinoco delta).

${ }^{b}$ Data compiled by Howard-Williams \& Thompson (1985) and Thompson (1996). Flood plains in Mozambique or Angola are not included because not enough information was available at the date of compilation (Howard-Williams \& Thompson 1985; Thompson 1996).

${ }^{c}$ Dadnadji and van Wetten (1993) report that wetlands along the Lagone and Chari cover totally $78000 \mathrm{~km}^{2}$ including inundated flats, riverine flood plains, marshes and smaller lakes.

${ }^{d}$ Plantations cover $50 \%$ of the remaining flood plains.

about $700000 \mathrm{~km}^{2}$ of all land (Kusler \& Larson 1993), but nowadays, about $50 \%$ of the unmodified flood plains occur in Alaska. Along the Mississippi, $90 \%$ of the flood plain (former area $123000 \mathrm{~km}^{2}$ : Sparks et al. 1998) is leveed, and has therefore become 'functionally' extinct, meaning that the basic attributes that sustain the flood plain such as regular flooding or morphological dynamics are gone. In Australia, the largest relatively intact flood plains can be found along Cooper Creek and other rivers of the Lake Eyre Basin in Central Australia (catchment: $1.14 \times 10^{6} \mathrm{~km}^{2}$ ) where, during floods, up to $106000 \mathrm{~km}^{2}$ of flood plains become inundated (Kingsford et al. 1998). The Lower Balonne River in eastern Australia also features a very large flood plain, with approximately $2500 \mathrm{~km}^{2}$ of flood plain regularly inundated (Sims \& Thoms 2002). Despite these examples, river regulation throughout much of south-east
Australia has altered the connection between flood plains and their parent rivers, resulting in loss of $18-90 \%$ of floodplain wetlands, according to type and region in the Murray-Darling Basin (MDBMC [Murray-Darling Basin Ministerial Council] 1995). The current situation for European flood plains is critical (see Wenger et al. 1990; Klimo \& Hager 2001; Hughes 2003), with 95\% of the original floodplain area converted to other uses (WWF [Worldwide Fund for Nature] \& EU [European Union] 2001) (Table 4.2). In 45 European countries, $88 \%$ of alluvial forests have disappeared from their potential range (UNEPWCMC [United Nations Environment Programme-World Conservation Monitoring Centre] 2004). Many of the remaining European flood plains are far from pristine and have lost most of their natural functions. For example, of the former $26000 \mathrm{~km}^{2}$ of floodplain area along the Danube 
(a)
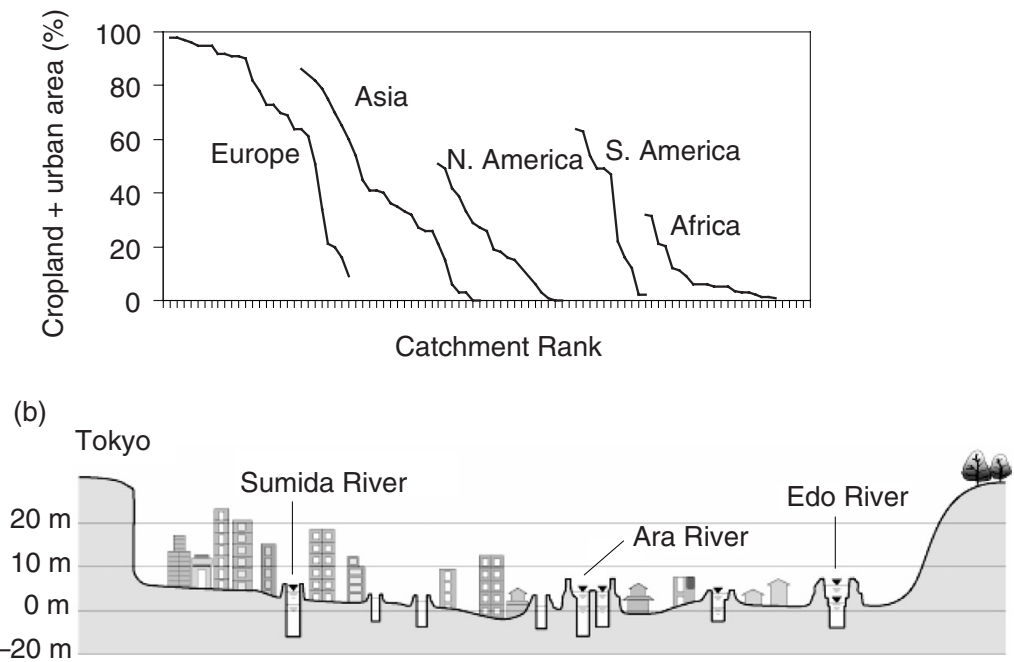

Fig. 4.2. (a) Relative proportions (\%) of riparian zones $(2 \mathrm{~km}$ along both sides of the river) along all major river corridors that have been transformed into urban or agricultural areas (total: 145 river corridors). River corridors are ranked for each continent from highest to lowest transformation rate (Revenga et al. 1998; Tockner \& Stanford 2002). (b) Cross-section of the Tokyo 'flood plain'. The flood water level is much higher than the surrounding ground level. (After Seki 1994.) and its major tributaries, about $20000 \mathrm{~km}^{2}$ are isolated by levees (Busnita 1967; Nachtnebel 2000). However, major flood events have highlighted the vast extent of plains still subject to flooding (Table 4.3).

\section{ECOLOGICAL VALUES OF FLOOD PLAINS}

Flood plains develop in all geographic regions and at different locations along river corridors (see Tockner et al. 2000; Junk \& Wantzen 2004). Flood plains are also topographically unique ecosystems occupying the lowest position in the landscape; they tend to integrate upstream catchment-scale processes. There exist some basic principles that drive the ecology of river-floodplain ecosystems (Bunn \& Arthington 2002). The flow regime determines the magnitudes of ecological processes and the temporal variability in floodplain communities and ecosystem processes. Fluvial dynamics, including the expansion/contraction of surface waters ('flood and flow pulses'), is also the driving force that sustains connectivity in flood plains and the river channel (Junk et al. 1989; Petts 1990; Tockner et al. 2000; Ward et al. 2002). Hydrologic connectivity, a key process in riverine flood plains, refers to water-mediated transfer of energy, matter and organisms within or among elements of riverine corridors (Ward et al. 1999; Pringle 2003). For example, diversity of birds and fish is significantly higher in floodplain waters with a natural hydrological regime compared to those with a regulated regime (Ward et al. 1999). Even small changes in the relative contribution of individual water sources may drastically alter species composition and diversity. For example, local groundwater upwelling (Chapter 3) is often associated with a higher standing crop of algae, higher zoobenthos biomass, faster growth rates of cottonwood trees and a higher species richness of woody and herbaceous plants (Harner \& Stanford 2003). Despite its overwhelming importance in flood plains, hydrology is often given only cursory attention in restoration and mitigation projects (e.g. Bedford 1996; see also Chapter 3).

Flood plains form a complex mosaic of landforms, communities and environments (Naiman et al. 1993). The exceptionally high biological diversity of floodplain ecosystems results from a number of attributes such as soil moisture availability, structural complexity, microclimate characteristics and nutrient enrichments. Indeed, far more species of plants and animals occur on flood plains than in any other landscape unit in most regions of the world. In the Pacific coastal ecoregion of the USA, for example, approximately $29 \%$ of wildlife species ranging from $12 \%$ of mammals to $60 \%$ of amphibians found in riparian 
Table 4.3. The maximum area flooded $\left(\mathrm{km}^{2}\right)$ and the economic damage caused by recent flood disasters, compared to the 1995 Kobe earthquake

\begin{tabular}{|c|c|c|c|c|}
\hline River, geographical area & $\begin{array}{l}\text { Year of } \\
\text { event }\end{array}$ & $\begin{array}{l}\text { Area flooded } \\
\left(\mathrm{km}^{2}\right)\end{array}$ & $\begin{array}{l}\text { Economic loss, } \\
\text { casualties }\end{array}$ & Source \\
\hline Odra river, Poland and Germany & 1997 & 6000 & $\$ 2$ billion & Swiss Re (1998) \\
\hline Mississippi, USA & 1993 & 60000 & $\$ 18$ billion & Swiss $\operatorname{Re}(1998)$ \\
\hline $\begin{array}{l}\text { Queensland and New South } \\
\text { Wales, Australia }\end{array}$ & 1990 & 220000 & na & Swiss $\operatorname{Re}(1998)$ \\
\hline $\begin{array}{l}\text { Rhine river, Germany and the } \\
\text { Netherlands }\end{array}$ & 1995 & na & $\$ 3$ billion & Swiss Re (1998) \\
\hline Yangtze river, PR China & 1998 & 640000 & $\begin{array}{l}£ 12.82 \text { billion, } \\
4000 \text { people died }\end{array}$ & Zong and Chen (2000) \\
\hline $\begin{array}{l}\text { Elbe river, Germany and Czech } \\
\text { Republic }\end{array}$ & 2002 & na & $\$ 12$ billion & Becker and Grünewald (2003) \\
\hline Red river, USA and Canada & 1997 & 2000 & $\begin{array}{c}\$ 0.22 \text { billion, } 28000 \\
\text { people evacuated }\end{array}$ & Simonovic and Carson (2003) \\
\hline Kobe earthquake, Japan & 1995 & & $\begin{array}{l}\$ 100 \text { billion, } \\
5500 \text { people died }\end{array}$ & Swiss $\operatorname{Re}(1998)$ \\
\hline
\end{tabular}

Note: na, not available.

forests are riparian obligates (Kelsey \& West 1998). Although less than $1 \%$ of the landscape of the western USA supports riparian vegetation, this vegetation provides habitat for more species of breeding birds than any other vegetation association (Knopf \& Samson 1994). Similarly, the dense paperbark and lowland monsoon forests which fringe the larger rivers of Kakadu National Park in northern Australia are an important habitat for birds, despite occupying a small part of the landscape (Woinarski et al. 1988; Morton \& Brennan 1991). In the Amazon basin, approximately 1000 flood-adapted tree species occur in flood plains. In a small floodplain segment upstream of Manaus (Mamirauá Reserve, Brazil), approximately 500 tree species have been identified, about $80 \%$ of which are flood-plain-specific (Wittmann 2002). The occurrence of a distinct flooding gradient seems to maintain high landscape heterogeneity and therefore biodiversity on Amazonian flood plains (Ferreira \& Stohlgren 1999). Despite these important attributes, flood plains remain one of the least investigated landscape elements in terms of their contribution to regional biodiversity (Sabo et al. 2005).

Flood plains are among the most productive landscapes on Earth, owing to continual enrichment by import and retention of nutrient-rich sediments from the headwaters and from lateral sources, and they are usually more productive than the parent river and adjacent uplands (for example E. Balian \& R. J. Naiman, unpublished data 2004). There is a positive correlation between fish catch and the maximum inundated floodplain area in African rivers, with fish yield being most influenced by the flood state in previous years (Welcomme 1975, 1979). The so called 'floodpulse advantage' (sensu Bayley 1995) was recognized by the ancient Egyptians, since tax levies were based on the extent of the annual flood of the Nile.

Globally, flood plains are key strategic natural resources and they will continue to play a pivotal future role as focal nodes for biodiversity and bioproduction. Due to their distinct position along a river corridor, they are influenced by changes in the river as well as alterations at the catchment/landscape scale, resulting in a dynamic ecosystem under threat from all sides.

\section{ECONOMIC VALUE OF FLOOD PLAINS}

Flood plains offer a remarkably diverse array of natural services and functions. They provide biodiversity, flood retention, a nutrient sink, opportunities for pollution control, groundwater recharge (Chapter 3), carbon sequestration, timber and food production, organic matter production and export, recreational facilities and aesthetic value. Some 
of these are complementary service functions and the benefits are experienced simultaneously, while others are in mutual conflict, so that exploiting one benefit implies loss of another (Barbier \& Thompson 1998; Acharya 2000). It is difficult to place quantitative values on some services without undertaking in-depth empirical socioeconomic research (Turner 2000), and the valuation of different functions and services of flood plains is likely to be context and location specific.

The services provided by flood plains are estimated to be worth $\$ 3920 \times 10^{9}$ per year worldwide, assuming a total floodplain area of $2 \times 10^{6} \mathrm{~km}^{2}$ with a value of $\$ 19580$ per ha per year (Costanza et al. 1997). In total, flood plains contribute $>25 \%$ of all terrestrial ecosystem services, although they cover only $1.4 \%$ of the land surface area (for discussions see Aselmann \& Crutzen 1989; Mitsch \& Gosselink 2000; Tockner \& Stanford 2002; Table 4.2).

The major services provided by flood plains include flood regulation (37\% of their total value), water supply (39\%) and waste treatment (9\%). The value of floodplain land in Illinois (USA) is estimated as high as $\$ 7500$ per ha per year, with $86 \%$ of the value based on regional floodwater storage (Sheaffer et al. 2002). Nitrogen removal, an important floodplain service, ranges from 0.5 to $2.6 \mathrm{~kg} \mathrm{~N}$ per ha per day (Tockner et al. 1999). Flood plains along the Danube are valued at $€ 384$ per ha per year for recreation and nutrient removal (Andréasson-Gren \& Groth 1995). Similarly, the nitrogen reduction capacity of Estonian coastal and floodplain wetlands is worth $€ 510$ per ha per year. The Danube Delta Biosphere Reserve area of 5800 $\mathrm{km}^{2}$ yields $5000-10000 \mathrm{t}$ per year of fish, equivalent to $\$ 6.3$ million annually; 15000 people within the delta and approximately 160000 people from adjacent regions depend at least partly on this fishery resource (Navodaru et al. 2001). The economic value of selected African wetlands, mainly flood plains, is in the range of $\$ 67-1900$ per ha per year (Schuijt 2002). The aggregated value of agricultural, fishing and fuel wood benefits of a Sahelian flood plain is \$34-51 per ha per year (Barbier \& Thompson 1998). The natural value of the flood plain would be even higher if other important benefits such as the role in pastoral grazing and recharging groundwater were included. Agricultural benefits of a planned irrigation project would, however, be only in the range of $\$ 20-31$ per ha per year. Firewood, recession agriculture, fishing and pastoralism generate $\$ 32$ per 1000 $\mathrm{m}^{3}$ of flood water, compared to a value of $\$ 0.15$ per $1000 \mathrm{~m}^{3}$ for irrigation. In the Inner Delta of the Niger River, over 550000 people with about 2 million sheep and goats use the flood plain for post-flood dry-season grazing (Dugan 1990). There are many other examples of how local communities make use of the productivity and services provided by flood plains. The benefits of natural flood plains are clear and multifaceted, especially in dry regions.

\section{HAZARDS AND HUMAN BENEFITS OF FLOOD PLAINS}

\section{The double-edged face of floods}

Instead of allowing rivers to fan out and take advantage of the natural flood-control function of flood plains, many governments have spent large amounts of money to force rivers into tight channels, which has encouraged human use of flood plains throughout the developed world (Fig. 4.2). Moreover, reclamation of flood plains has often led to a massive increase in peak flow in downstream sections. Nowadays, about half of Europe's population and $c .70 \%$ of Japanese people live on flood plains (Statistics Bureau of Japan 2003). Despite engineering efforts to control rivers and protect life and property, flood losses continue to increase in most parts of the developed world. Floods are among the costliest natural disasters worldwide, in particular where human encroachment is intense (for example Burby 2002; Table 4.3). According to the Emergency Disaster Database (EM-DAT 2004), in the period from 1900 to 2004, floods affected 2.9 billion people, with 2.9 million killed and $>130$ million made homeless worldwide. In Japan, the average annual flood damage costs are $\$ 1.53$ billion (Seki 1994). In the USA, with 6 million buildings located within the boundaries of a 100-year-old flood plain, flood losses are widespread, have increased dramatically over the last few decades (the average damage cost is $\$ 115$ million per week) and will continue to do so over the next decades (Congressional Natural Hazard Caucus Work Group 2001). Industrial complexes in floodplain areas are also potential sources of contamination. For example, during the recession phase of the Elbe floods in Central Europe in 2002, threats from dioxin, mercury and other contaminants arose from flooding of sewage plants and release from river and floodplain beds.

Whereas the increasing exposure of property to flood risks is likely to be responsible for the major increase in flood damage over the next decades (Mitchell 2003), the invasion of flood plains by humans in search of new land for farming and homes is one of the most important drivers of flood losses in economically developing countries. In Bangladesh, flood plains occupy $80 \%$ of the country and 
annual flooding (locally known as borsha) is a part of peasant life to which people are resilient, since one-fifth of the country is regularly flooded (Mirza 2002, 2003) (Fig. 4.3c). Regular flooding is viewed as beneficial; it creates and maintains the high fertility of soils and supports the world's most densely populated country (average population density 1209 persons $\mathrm{km}^{-2}$ : Haque \& Zaman 1993; World Bank 2002).

Increasing population density has increased the vulnerability of human people to flooding. This increasing risk has led to the development of multiple large-scale management plans including the construction of large dams in upstream regions (for example Nepal), high embankments and bypass channels. All of these plans, however, ignore the multiple benefits of the natural flood regime.

\section{The cultural value of flood plains}

The multiple resources provided by flood plains have favoured the development of ancient cultures along the Nile, the Euphrates and the Indus. Rice cultivation started in China about 7000 years ago (Boulé 1994) and continues to be the nutritional basis for much of the human population worldwide. In the flood plain of the Amazon River,
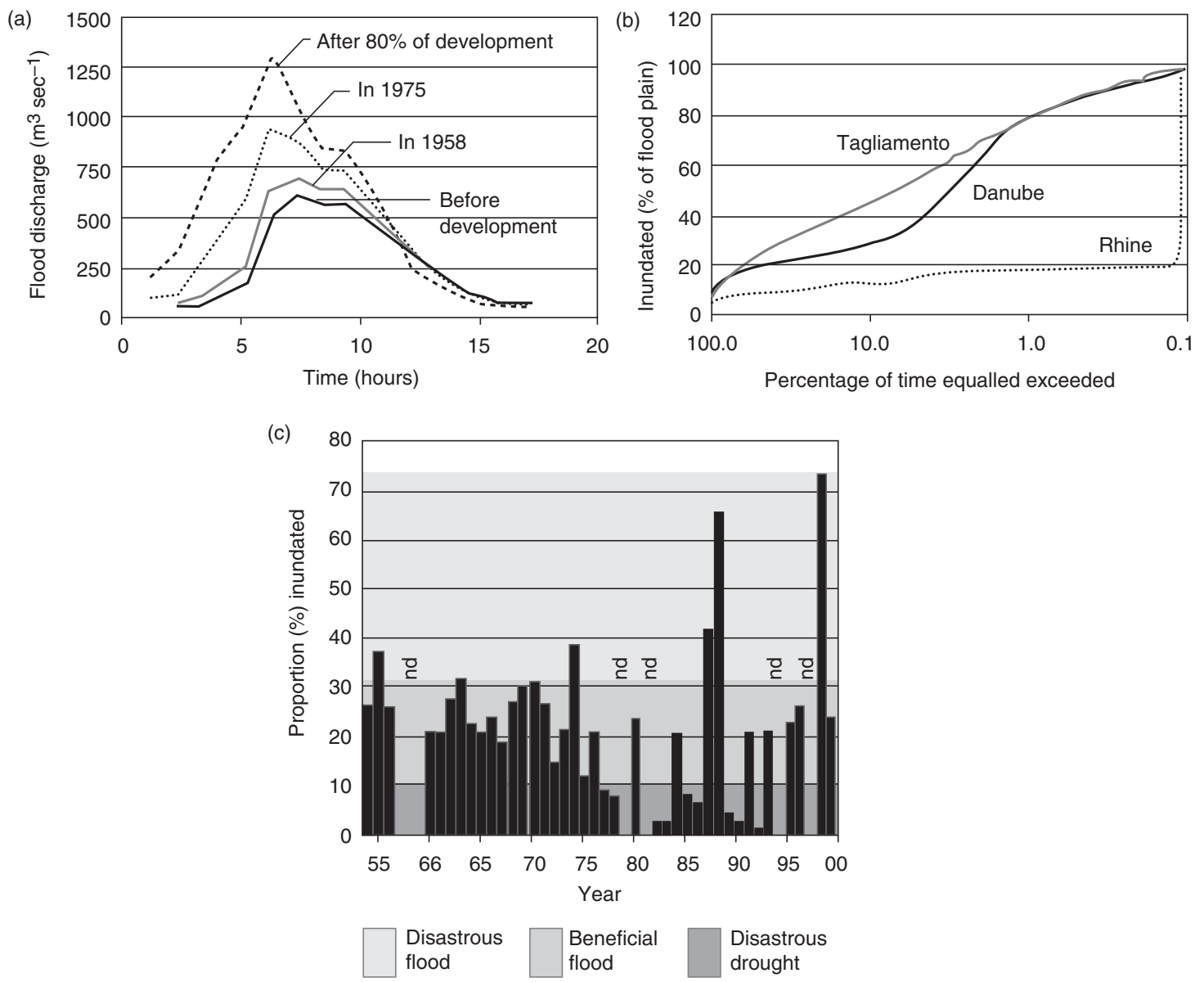

Fig. 4.3. (a) The impact of floodplain development (primarily urbanization) on flood discharge in the Tsurumi River (Kanto plain, Japan) (after Sakaguchi 1986). (b) Inundation-duration curve for a natural (Tagliamento, Italy), a regulated (Danube, Austria) and a channelized (Rhine, the Netherlands) river-floodplain system. (Data from Rhine: T. Buijse, personal communication 2003). (c) Historic flood events in Bangladesh. The relative proportion (\%) of the country that has been inundated during the annual flood (1954-1999) (after Mirza 2003). Eighty per cent corresponds to an inundated area of 110 $000 \mathrm{~km}^{2}$. Beneficial floods, disastrous floods and droughts are distinguished. nd, no data. 
Box 4.1. Outcast of Eden

'At the height of the floods great tracts of the desert adjoining the marshes are covered by sheets of open water that vary each year in size but can extend for a distance of more than two hundred miles from the outskirts of Basra almost to Kut. As the floods recede most of this inundated land reverts into desert' (Thesiger 1964). At the edge of the Mesopotamian wetlands, human history in Iraq began. By the fifth millennium BC the ancient Madan (Marsh Arabs) built reed houses, made boats and harpooned and netted fish. This was considered to be the true Garden of Eden. The Madan are considered the oldest people worldwide, with direct ethnic links back to the Sumerians and Babylonians.

The Mesopotamian marshlands were one of the world's greatest wetlands, covering an estimated area of $20000 \mathrm{~km}^{2}$, and an important centre of biodiversity, playing a vital role in the intercontinental migration of birds. By the 1990s, more than $90 \%$ of the former wetlands had been transformed into bare land and salt crusts. The creation of large reservoirs in the upstream sections (for example the Southeastern Anatolia Project [GAP], URL http://www. gap.gov.tr) and, in particular, the active drainage of the wetlands themselves led to the collapse of the entire ecosystem complex (Gleick et al. 2001; UNEP [United Nations Environment Programme] 2001a). Draining the wetlands was done primarily to punish the Madan after they started a rebellion against the Saddam Hussein regime following Gulf War I; most of the wetland area disappeared between 1992 and 1994 (Munro \& Touron 1997).

The destruction of these Mesopotamian wetlands is one of the world's great environmental disasters, affecting the ecology, and social, cultural and economic base of the Madan. Hundreds of thousands of Madan are internally displaced within Iraq, while $c .40000$ seek refuge in nearby Iran (UNEP 2001a). The impact on biodiversity has included the loss of several endemic vertebrates (UNEP 2001a).
pre-Columbian human population density was several times higher than in adjacent uplands (Junk \& Wantzen 2004).

Flood plains are inhabited by a variety of indigenous human societies that are well adapted to the conditions and have developed a rich local culture. Many of these peoples are already listed as threatened and there is a great risk that the ongoing environmental impact on large river-floodplain complexes will also increase the future risk of their extinction (Box 4.1). Examples include the Lotzi ('Water People') in the Borotse flood plain (Zambezi River basin, southern Africa), the Tonga people in the Kafue flood plain (Zambezi River basin, southern Africa) or the Ogoni in the Niger delta (Nigeria), the last threatened by oil exploitation in addition to changing hydrology. The Nuer, Dinka and Shiluk in the Sudd area (Nile) are threatened by civil war and by the construction of the Jonglai Canal.

\section{MAJOR DRIVERS IN FLOODPLAIN CHANGE}

Flood plains are among the most altered landscapes worldwide and they continue to disappear at an alarming rate, since the 'reclamation' rate is much higher than for most other landscape types (Vitousek et al. 1997b; Olson \& Dinerstein 1998; Revenga et al. 2000). The decline of floodplain diversity is much greater than that of terrestrial systems (Stein 2001), which is attributable to habitat alteration, pollution, competition for water, invasive species and overharvesting (Abramovitz 1996). Among these factors, land transformation including alteration of flow regime is the single most important cause of species extinction (Vitousek et al. 1997b). Habitat degradation and loss contribute to the endangerment of $85 \%$ of the threatened species in the USA (Wilcove et al. 1998). Drivers such as climate change, species invasion and habitat degradation also cause irreversible changes, at least on ecological timescales from decades to centuries.

For river-floodplain ecosystems, expected impacts vary latitudinally. In tropical ecosystems, land use is expected to have the greatest effect, with climate change being minimal. In temperate systems, both land-use change and invasion of non-native species can be expected equally to affect biodiversity, and in high latitude/altitude systems climate change is by far the most dominant driver, although region-specific differences exist (Sala et al. 2000). Anthropogenic threats to river-floodplain biodiversity will differ between economically developed and developing countries (Table 4.4).

\section{Human population growth}

Increase in human population will be by far the most important driver in future biodiversity change in the developing countries. The current annual human population 
Table 4.4. Different states and future trends in developing and developed countries

\begin{tabular}{lll}
\hline \hline & Developing countries & ${\text { Developed } \text { countries }^{a}}$ \\
\hline Population growth 2000-25 (\%) & $2-3$ & \pm 0 \\
Human population in 2025 (billions) & 6.4 & 1.6 \\
Water abstraction (\% increase 2000-25) & +50 & +18 \\
Present water use for agriculture (\% of total withdrawal) & 82 & 30 \\
Urbanization (\% in 2025) & 50 & 75 \\
Increase in hydropower production (\% 1995-2010) & +100 & +10 \\
Mega-biodiverse countries & 9 & 1 \\
Global hotspot areas & 20 & 5 \\
Major future impacts & Urbanization, pollution, & Morphological modification, \\
& abstraction, climate change & pollution, climate change \\
Major measures required & Conservation, pollution control & Restoration \\
\hline \hline
\end{tabular}

${ }^{a}$ Mainly Member States of the OECD (Organization for Economic Cooperation and Development).

Source: UN (1999); Cosgrove and Rijsberman (2000); Meyers et al. (2000); IUCN (2000); UNEP (2001b, 2003).

increase of 80 million will probably remain constant until 2015 (Fischer \& Heilig 1997). The total population growth from 6 billion in 2000 to an expected 8 billion in 2025 will be generated almost exclusively in developing countries, primarily in Asia, although average annual growth rates will be highest in Africa (Chapter 1). The regions that will experience the largest difficulties in meeting future demand for land resources and water, or alternatively will have to cope with increased dependency on external supplies, include western and south-central Asia, and northern Africa. A large stress on resources is to be expected also in many countries in the remainder of Africa (Tinker 1997). The strong population momentum indicates the next 20-30 years to be the most critical for achieving food security. Since remaining natural flood plains generally promise high food production rates, these are expected to be among the first ecosystems to disappear. High human population growth rate, fast economic development and limited financial resources for conservation will lead to a disproportional impact on global biodiversity in developing countries (Table 4.4).

\section{Climate change}

More intensive precipitation events over many areas, increased summer drying over most mid-latitude continental interiors and associated risks of drought, and higher minimum temperatures are likely to result from climate change (IPCC 2001b). These could increase the risk of abrupt and non-linear changes in flood plains, affecting their function, biodiversity and productivity. A warming of the air by $3-4^{\circ} \mathrm{C}$ is predicted to eliminate $85 \%$ of all remaining wetlands (UNEP \& WCMC 2004). Projected effects for flood plains include lower water levels during the growing season and higher mean water temperatures. The return period of extreme precipitation events could decrease almost everywhere. Climate simulations have suggested that global warming induced by greenhouse gases would lead to a moistening of the atmosphere (7\% per degree warming) and an intensification of the hydrological cycle. Numerical modelling carried out in Europe for the fall season predicts a substantial shift towards more frequent large-precipitation events, in particular in southern Europe and in the Alpine regions, since these areas are expected to be particularly receptive to the 'moisture effect' (Frei et al. 1998). For North Carolina, an increase in precipitation of $15 \%(5-30 \%)$ is predicted by 2100, which will shift floodplain boundaries and make recent human developments in floodplain areas especially vulnerable to flood damages. Similar effects are predicted for the Pacific Northwest (USA). In 2070, for example, floods that now have 20-year return periods are projected to occur twice as often (Zwiers \& Kharin 1998). For the eastern USA, a 10\% decline in annual runoff could result in a nearly $50 \%$ increase in intermittent streams (Poff 1992). In the Fraser River (British Columbia, Canada), 
annual floods may occur on average 24 days earlier in 2070 , summer temperature may increase by $1.9^{\circ} \mathrm{C}$, and the potential exposure of salmon (Oncorhynchus spp.) to water temperatures above $20^{\circ} \mathrm{C}$, limiting their spawning success, could increase by a factor of 10 (Morrison et al. 2002). Palaeoecological evidence suggests that droughts are likely to occur more frequently in the future in Australia, where anthropogenic effects are likely to exacerbate the trend (Humphries \& Baldwin 2003).

\section{Flow modification}

The alteration of flow regimes is the most serious and continuing threat to the ecological integrity of riverfloodplain ecosystems (Nilsson \& Berggren 2000; Bunn \& Arthington 2002; Naiman et al. 2002) by reducing flood peaks, flooding frequency and duration, and changing the nature of dry periods (McMahon \& Finlayson 2003). These flow changes reduce lateral connectivity between the flood plain and parent river, disrupt sediment transport and reduce channel-forming flows. Inundationduration curves used to assess the hydroecological integrity of these ecosystems indicate an almost linear relationship between water level and inundated area in natural flood plains (Benke et al. 2000; Van der Nat et al. 2002) (Fig. 4.3b). In regulated rivers such as the Austrian Danube, floodplain inundation is short and the increase in inundation area is abrupt. Along channelled rivers, flood plains only receive surface flooding from the river during major flood events (see Table 4.3). Large-scale floodplain development and water-resource development often lead to major decreases in the reactive floodplain area. For example, the Barmah-Millewa Forest on the upper Murray River (Australia) is the largest remaining river red gum (Eucalyptus camaldulensis) forest in Australia and is in part listed under the Ramsar Convention. Regulation of river flows in the upper catchment has largely alienated the flood plain from the river, and flooding of the forest has been reduced from $80 \%$ to $35 \%$ of years (Close 1990). Reduced flooding frequency has changed the community composition, growth and regeneration of the floodplain vegetation (Chesterfield 1986; Bren 1988). A similar fate has befallen the Macquarie Marshes in the upper MurrayDarling Basin. These major floodplain wetlands at the end of the Macquarie River cover about 130000 ha during large floods. Water diversion from the Macquarie River has greatly reduced the area of floodplain inundation and the Macquarie Marshes have contracted to $40-50 \%$ of their original size (Kingsford \& Thomas 1995). The abundance and species richness of waterbirds in the northern part of the Macquarie Marshes have declined as a consequence and major changes in the composition of floodplain vegetation have also occurred (Kingsford 2000).

Changes in catchment hydrology, caused by clearing of native vegetation for agriculture, have also led to a marked increase in dryland salinity in some Australian flood plains (Box 4.2).

\section{Species invasion and pollution}

Species invasion is one of the most important causes of the overall decline in aquatic biodiversity. The higher percentage of exotic plants and animals in flood plains compared to uplands demonstrates the vulnerability of the riparian zone to invasion (Pysek \& Prach 1993). Despite great differences in climate, species richness and land-use history, $20-30 \%$ of species in riparian corridors of Europe, the Pacific Northwest (USA) and South Africa are invasive (Hood \& Naiman 2000; Tabacchi \& Planty-Tabacchi 2000). Fourteen of the top 18 environmentally noxious weeds in Australia occur in flood plains and wetlands (Humphries et al. 1991; Bunn et al. 1997), and species such as Mimosa pigra and Urochloa mutica have had major impacts in the largely undeveloped floodplain river systems of the Australian wet-dry tropics (Douglas et al. 1998). Although invasive species are frequently responsible for the decline of native species, the introduction of exotic species may increase overall diversity, although the impacts of exotic species may vary at different spatiotemporal scales (Sax \& Gaines 2003).

Pollution is still a major issue in both the economically developed (for example Van Dijk et al. 1994) and developing countries. In developing countries, an estimated $90 \%$ of wastewater is discharged directly into rivers without treatment (Johnson et al. 2001). For example, in China, $80 \%$ of the $50000 \mathrm{~km}$ of major rivers are too polluted to sustain fisheries and fish have been completely eliminated from 5\% (FAO [Food and Agricultural Organization of the United Nations] 1999). In Poland, $75 \%$ of the water in the Vistula, which retains many seminatural flood plains, is unsuitable even for industrial use (Oleksyn \& Reich 1994). High nutrient concentrations of the parent river are also a major obstacle to restoring flood plains along many rivers such as the Danube and Rhine (Buijse et al. 2002). 
Box 4.2 Dryland salinity issues for flood plains

Salinity is a natural feature of the Australian landscape, particularly in the drier regions of the south-west and south-east, the combination of several factors making dryland salinity a significant problem to both terrestrial and aquatic ecosystems (see Chapters 2, 3, 10). Native Australian vegetation has evolved to take full advantage of available water, and little movement of rainwater into the root zone typically occurs (for example 1-5 mm per year) in dry lands. The low topographical relief, poor drainage and older, less permeable soils are conducive to accumulation of salt. These conditions have meant that salts are not flushed from the landscape, reaching levels of over 10000 t per ha in some regions (Hatton \& Salama 1999).

Clearing of catchments for dryland cropping and grazing has replaced deep-rooted perennial native vegetation with shallow-rooted annual species, allowing more rainfall to penetrate the deeper soils, causing water tables to rise. Wherever the groundwater contains salt or intercepts salt stored in the landscape, salt is mobilized to the land surface and ultimately into streams, rivers and wetlands. In the drier parts of this region (rainfall $<900$ mm per year), catchments with as little as $10 \%$ of the native vegetation removed have streams with marginal salinities (Schofield et al. 1989). The problem has been compounded by irrigation (e.g. in parts of the MurrayDarling Basin in south-east Australia), where the water use has hastened rises in groundwater levels, and increasing regulation of rivers by dams and weirs and diversion of water have reduced the natural flushing.

Dryland salinity currently affects 1.8 million ha in Australia and may rise to 15 million ha in the next 50 years (PMSEIC [Prime Minister's Science, Engineering and Innovation Council] 1998). The economic costs are currently estimated at $\mathrm{A} \$ 700$ million in lost land and A $\$ 130$ million per year in lost production. Salinity is degrading rural towns and infrastructure, as seen in crumbling building foundations and roads. In the lower Murray River in South Australia, salinity is projected to rise to a level close to the World Health Organization limit of $800 \mathrm{EC}$ units for desirable drinking over the next 50 years. In some northern parts of the Murray-Darling Basin, river salinity will rise to levels that will seriously constrain the use of river water for irrigation.

Biological effects of secondary salinization include losses of remnant vegetation, riparian vegetation, wetlands and aquatic biota. About 25\% of the Murray River flood plain in south Australia is currently affected by salt, and this could rise to $30-50 \%$ within 50 years (MDBMC 1999). The Ramsar-listed Chowilla Wetlands are under serious threat and without intervention more than half of the 20000 ha will be lost (MDBMC 1999). About $80 \%$ of the length of streams and rivers in south-western Australia are degraded by salinity and half of the waterbird species have disappeared from wetlands that were once fresh or brackish (PMSEIC 1998).

The area of salinized land in Australia is likely to at least triple in the short term and further losses of biodiversity and ecosystem services can be expected. Extensive catchment revegetation to control recharge would be required to reverse these trends but, even then, response times would be slow (Hatton \& Salama 1999). Engineering solutions (for example pumping) can have local effects on water levels if maintained over long timescales; however, there are obvious impacts associated with off-site disposal of saline groundwater. Investment in restoration may be better placed elsewhere or at least focused on protecting key assets (Hatton \& Salama 1999).

\section{FORECASTING ENVIRONMENTAL FUTURE OF FLOOD PLAINS}

Quantitative forecasting of the ecological state of flood plains over the next decades, in the face of increasing human population density, climate change and changing land use, is a difficult goal (Nilsson et al. 2003). For example, accurate methods to forecast land use changes over a period of 20 years or more are not available, especially not at spatially explicit scales. A logical approach to coping with uncertainty in predicting the environmental future is to develop alternative scenarios since they focus our attention on the unusual, the uncertain and the surprising when making decisions (Sala et al. 2000; Bennett et al. 2003).

Long-term ecological data in freshwater and wetland habitats are rare, and this makes it difficult to determine whether observed changes are part of long-term environmental trends or responses to specific human actions. Qualitative information on population trends (increasing, stable, decreasing) of more than 200 freshwater, wetland and 
water margin vertebrate species indicates most species are declining in population size (WWF 1999). Quantitative data are available for only 70 species. An index generated from these data shows a decline of around 50\% from the 1970 baseline, which is a much greater decline than for terrestrial or marine biodiversity (Tockner \& Stanford 2002).

The time lag between habitat loss and species disappearance means that measured extinction rates have considerable inertia. The effect of the main drivers on an ecosystem is also expected to be non-linear, including major time lags between impact and response. The response of a biological community to its modified habitat condition can take a century or more, especially for organisms with long life cycles (like riparian trees), and is a potential source of misleading interpretations. This also implies that present-day activities may not yield demonstrable changes for several years or even for decades. Floodplain examples of lag times in the range of decades to centuries between onset of an impact and biodiversity response include riparian flood control (Poiani et al. 2000), and invasion of riparian ecosystems by exotic plants (Pysek \& Prach 1993). The results of these studies set the timescale over which humanity must take conservation actions in impacted terrestrial and aquatic ecosystems (years to several decades).

Land-use change is the major environmental driver of the condition of freshwater ecosystems. At the global scale, the land area significantly impacted by human activities may increase from $15-20 \%$ to $50-90 \%$ within 50 years, and pressure on flood plains will be among the highest (UNEP $2001 b$ ). Flood plains are often the focus of urban or agricultural development. The Caspian region, the Middle East, parts of Argentina and Chile, south-east Africa and SouthEast Asia have been identified as the most critical regions of water resource vulnerability with respect to climate change and land use within the next 20 years (Kabat et al. 2002). In South-East Asia, the combined effects of climate change, human population growth and economic development will increase the pressure on freshwater biodiversity probably more than in any other part of the world. In particular, aquatic organisms will be affected by water pollution, flow regulation, habitat degradation and exotic species invasion (Dudgeon 2002). None of these threats is unique to SouthEast Asia, but the rate and extent of environmental change in Asia is exceptional. In Asia, more than $5000 \mathrm{~km}^{2}$ of wetlands are lost every year because of agricultural development, urbanization and dam construction (McAllister et al. 2000). If this trend continues, which is probable because of rapid economic and demographic development, by 2025 an additional $105000 \mathrm{~km}^{2}$ of wetlands will be converted to other uses. In particular, India and China belong to the rapidly developing countries where an increasing demand for water from a growing population and rapid economic development will lead to substantial water shortages. In 2025, India, Pakistan and China are expected to join the list of those countries where per caput water availability will fall below the critical threshold of $c .1500 \mathrm{~m}^{3}$ per year (Zehnder et al. 2003). The increasing water demand for agriculture and industry will reinforce the current pressure on flood plains. It is predicted that China will be able to feed its population in the future only if all rivers are dammed and no fresh water reaches the sea except during major floods. The ecological consequences for river-floodplain ecosystems are expected to be disastrous.

In the Ganges-Brahmaputra-Meghna Basin, an increase in seasonal and interannual variability, as already experienced during the past 20 years, can be expected (Fig. 4.3c). India is also planning to invest $€ 100$ billion within the next 15 years to build 32 large dams for transferring water from large rivers such as the Ganges to water-scarce areas via c. $10000 \mathrm{~km}$ of new canals. The irrigation of $350000 \mathrm{~km}^{2}$ more land should allow a doubling of present Indian food production within 50 years (Anon. 2003). Freshwater ecosystems will obviously be affected.

\section{FLOODPLAIN MANAGEMENT REQUIREMENTS}

\section{Inventory and indicators}

In spite of the Convention on Biological Diversity (1992), there is still no programme to document changes in biodiversity in natural habitats and the dearth of information on trends at the global scale is therefore not surprising (but see UNEP 2001b). For example, there exist no global estimates of rates of change in the extent of flood plains or in their conditions (Jenkins et al. 2003). The estimated percentage of wetland area in Africa ranges between $1 \%$ and $16 \%$ as a result of problems of wetland definition and limited scientific knowledge (Schuijt 2002). Even for vertebrates, available data are inadequate for discerning reliable population size trends for flood plains. There is a critical need for better and more up-to-date environmental data to determine trends. Flood plains need to be inventoried in a way that identifies the level of anthropogenic impact, for example: (1) natural flood plains (2) semi-natural flood plains (with a 
sustainable use), (3) flood plains with a high degree of reversibility (see Amoros \& Petts 1993), (4) flood plains with a very low degree of reversibility and (5) degraded flood plains. A list of the mostly natural areas can provide a guide to opportunities for effective conservation. These are also those areas where the widest range of biodiversity might be conserved with a minimum of conflict, and might be seen as seeds of wilderness (Sanderson et al. 2002). Indeed, in Europe, North America and Japan, there are few remaining dynamic flood plains (see Fig. 4.1a) where large-scale natural disturbance events still occur.

The selection of indicators of environmental conditions is crucial for the interpretation of environmental changes. These indicators need to be integrated over different spatial and temporal scales. For example, changes in biodiversity and ecosystem processes are expected to differ among different scales. A major decline in biodiversity at one scale can be contrasted by an increase in biodiversity at another scale, as demonstrated in recent empirical studies (Sax \& Gaines 2003).

\section{Cost-benefit calculations}

The flood plains of large rivers can no longer be regarded as wastelands suitable for draining and agricultural development. One move towards resolving the difficulties now besetting the world's rivers and flood plains is an ecosystembased approach to management, which includes careful cost-benefit calculations. For example, cost-benefit analyses are available for the Elbe flood plains (Germany), which may serve as a model for comparable management projects. This project considers, beside other measures, the reintegration of $150 \mathrm{~km}^{2}$ of former flood plains. Although these areas will only slightly mitigate future flood damage, there will be major ecological benefits. Even under very conservative assumptions, the benefits outweigh the costs and for each $€ 1$ invested, a return of $€ 2.5$ is expected via increased ecosystem services such as higher nutrient removal rates. The Elbe River clearly shows that restoration of flood plains is economically beneficial to society (Meyerhoff \& Dehnhardt 2002).

\section{Environmental flow requirements and management}

There has been a major move toward the evaluation of river flow regimes in relation to the needs of natural ecosystems (both in streams and on flood plains) as legitimate users of fresh water, as well as those from agriculture, industry and domestic water supply (King \& Louw 1998; Arthington \& Pusey 2003) (Fig. 4.4). Both high flows and low flows may be managed (in terms of the timing, frequency, magnitude and duration of flow regimes) to encourage sustainable river-floodplain ecosystems (Lambs \& Muller 2002; Hughes \& Rood 2003). Unfortunately, the amount of water allocated to rivers through environmental flows is rarely enough to replace the small to medium floods that regulation and abstraction have affected. In these situations, water is best targeted on key floodplain resources, such as Ramsar wetlands. There are exceptions

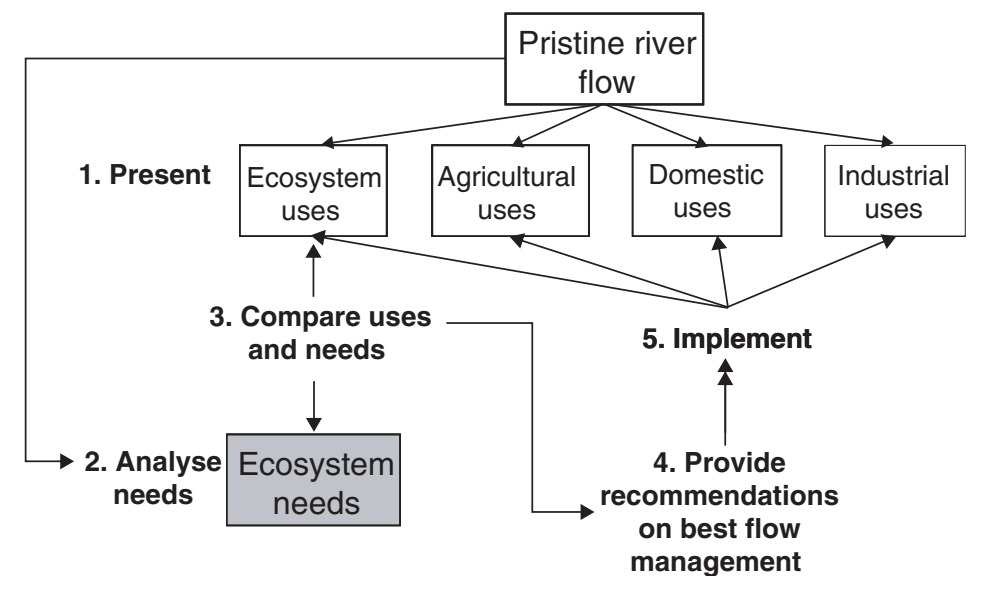

Fig. 4.4. Adaptive management to allocate water for ecosystems.

(After C. Nilsson, personal communication 2004.) 
where environmental flows can benefit whole flood plains. For example, in Cameroon, a flood plain is being brought back to life through the Waza-Lagone rehabilitation scheme. Water released through newly constructed openings in the main river levee has enabled restoration of about $60 \%$ of the dam-affected flood plain (Bergkamp et al. 2000).

\section{Institutional framework and floodplain restoration}

The twenty-first century has frequently been designated as the century of nature restoration, at least in the developed world. However, major difficulties exist in the implementation of restoration schemes. Firstly, there is a perceived conflict between the goals of flood management and ecological conservation or restoration, which partly reflects the different values and paradigms within organizations and corresponding institutions (e.g. Pahl-Wostl 2002). Secondly, there are conflicts that arise because of the transboundary nature of many major river ecosystems, with the attendant problems of continuity of floodplain management policy and practice between upstream and downstream riparian states with different environmental priorities. Thirdly, a tension exists between water management, land-use planning and other aspects of environmental management.

Viable floodplain management can only be achieved when property owners, developers, environmental activists and governmental officials at all levels work together (Naiman 1992). It must be recognized that floodplain management is a public-private venture (flood control vs. land ownership). Incentives are suitable for floodplain management because they consider private as well as public benefit (Sheaffer et al. 2002). A positive example is the recent initiation of a new approach to flood mitigation and river restoration by the US Army Corps of Engineers. In a pilot phase, the Corps pays $65 \%$ of the costs of resuming properties on flood plains, tear down dams and dykes, and relocate property owners. The local communities finance the remaining 35\%. Initial results demonstrate a high interest by communities and affected people in the property buyouts on the USA's flood plains (IUCN 2000).

\section{CONCLUSIONS}

Flood plains are unique and dynamic ecosystems that link rivers with their catchments. They are highly productive environments, supporting a diverse biota, but are also intensively used by humans for agricultural and urban development, resulting in loss of biodiversity and ecological functioning. The priority for flood plains is to conserve those that are still intact and to attempt to rehabilitate those that are degraded. In both cases, protecting or restoring key components of the natural flow regime is essential, while maintaining sustainable use of floodplain resources by local communities, particularly in developing countries. Finding this compromise between conservation and resource use requires a greater understanding of the role of flow relative to other stressors in driving ecological processes in flood plains. Floodplain management and restoration strategies must also take into account climate change models that predict significant changes to flow regimes in most of the world's rivers, especially in temperate and arid regions. 
